\title{
Cardiovascular Risk Factors in Children and Adolescents with Subclinical Hypothyroidism: A Meta-analysis and Systematic Review
}

Huan DENG ( $\nabla$ dengh1027@163.com)

Hospital of Chengdu University of Traditional Chinese Medicine

Research

Keywords: Children, adolescents, subclinical hypothyroidism, cardiovascular, lipid

Posted Date: November 10th, 2021

DOI: https://doi.org/10.21203/rs.3.rs-1023396/v1

License: @) (i) This work is licensed under a Creative Commons Attribution 4.0 International License. Read Full License

Version of Record: A version of this preprint was published at Medicine on July 31st, 2020. See the published version at https://doi.org/10.1097/MD.0000000000020462. 


\section{Abstract}

Introduction: Subclinical hypothyroidism( $\mathrm{SCH})$ is serum thyrotropin slightly increased, while serum free thyroxine level in the normal range, many studies are proving that $\mathrm{SCH}$ does increase cardiovascular risk in adults. However, current studies on cardiovascular risk in children and adolescents with SCH have not been conclusive. Therefore, we did a meta-analysis and systematic review of the included case-control and cross-sectional studies to make up for the lack of data in this direction.

Methods: We searched the following databases from its inception until May 9, 2020: PubMed, EMBASE, Web of Science, Cochrane Library, CNKI, Wanfang, and VIP. The Newcastle-Ottawa Scale was be used to check on the quality of these studies. $\left.\right|^{2}$ statistics and subgroups were be used to analyze heterogeneity. The sensitivity analysis assessed the stability of the results against the overall effect by "leave-one-out". When the systematic review contains more than 10 articles, funnel plots and egger regression test was be made to evaluate publication bias.

Result: Twelve observational studies were enrolled in our meta-analysis. TC was significantly higher in SCH patients than in normal thyroid subjects (WMD=6.01, 95\% Cl: 3.70-8.31, P<0.00001), TG (WMD=9.86, 95\% Cl: 5.72-14.01, P<0.00001), LDL (WMD=4.33, 95\% Cl: 1.78-6.87, P=0.0009), and IVRT $(\mathrm{WMD}=7.85,95 \% \mathrm{Cl}: 3.99-11.72, \mathrm{P}<0.0001)$. At the same time, we found no significant differences in HDL, IMT, and HOMA-IR between the two groups.

Conclusions: Our study confirmed that $\mathrm{SCH}$ changes lipid profile and heart function in children and adolescents.

Register: The protocol of this systematic review and meta-analysis was registered on the NPLASY (No. 202040182). The protocol has been published, it can be found in https://pubmed.ncbi.nlm.nih.gov/32756074/.

\section{Introduction}

Subclinical hypothyroidism ( $\mathrm{SCH}$ ) is serum thyrotropin (TSH) slightly increased, while serum free thyroxine (FT4) level in normal range ${ }^{1,2}$. In some respects, $\mathrm{SCH}$ can be regarded as a mild loss of thyroid, which is brought about by various reasons. Including congenital and acquired primary thyroid diseases ${ }^{3,4}$, one of the most important causes is autoimmune thyroid disease.

The upper limit of normal TSH levels is different from different age groups ${ }^{5,6}$. The normal upper limits to the thyroid-stimulating hormone in adults and children are usually set at about 4.0-5.0 mIU/L ${ }^{7}$. According to the level of TSH, SCH can be divided into two categories: When TSH value is less than $10 \mathrm{mIU} / \mathrm{L}$, it is defined as mild SCH, Conversely, it is severe $\mathrm{SCH}^{8}$. In children, the incidence rate of $\mathrm{SCH}$ is less than $2 \%^{9}$. The probability of SCH progressing to overt hypothyroidism is approximately $2 \%$ to $6 \%$ per year $^{10}$.

As we all know, the thyroid hormone has anti-atherosclerotic effects ${ }^{11}$. A large and growing body of research ${ }^{12-16}$ has confirmed that hypothyroidism accelerates the atherosclerotic in several ways, such as lipid profile ${ }^{12-14}$, blood pressure ${ }^{15}$, and endothelial function ${ }^{16}$, it also has a direct impact on cardiovascular function ${ }^{17}$. At the same time, many studies ${ }^{18-20}$ are proving that $\mathrm{SCH}$ does increase cardiovascular risk in adults. It comprises the following aspects: left ventricular diastolic function ${ }^{18}$, arterial function ${ }^{19}$, lipid profile ${ }^{20}$, and more. However, because of the small sample size and various confounding factors, current studies on cardiovascular risk in children and adolescents with SCH have not been conclusive. Therefore, we did a metaanalysis and systematic review of the included case-control and cross-sectional studies to make up for the lack of data in this direction, objective to compare the differences in cardiovascular risk causes between children and adolescents with and without SCH, including lipid profile parameters, intimamedia thickness (IMT), insulin resistance, and isovolumic relaxation time (IVRT).

\section{Methods}

A meta-analysis of Observational Studies in Epidemiology (MOOSE) ${ }^{21}$ was strictly implemented in our study. The protocol for this study has been published. The article can be found in https://pubmed.ncbi.nlm.nih.gov/32756074/.

\subsection{Search strategy}

We searched the following databases from its inception until May 9, 2020: PubMed, EMBASE, Web of Science, Cochrane Library, CNKI, Wanfang, and VIP. At the same time, we also looked up by reading the references. A search strategy was developed using a combination of medical subheadings (MeSH) words and keywords related to Subclinical hypothyroidism, children and adolescents, cardiovascular. Mesh words include 'child', 'Adolescent', 'pediatric', 'Subclinical hypothyroidism' 'cardiovascular', 'lipids', 'Insulin Resistance', 'intima-media thickness' and 'Atherosclerosis'.

Two investigators (HD, PPH) reviewed the article separately, and discuss it with the third member (XLQ) in case of a dispute. For articles in incomplete data, we contacted the author by email to obtain the full text or required data. If there are 2 or more articles from the same group of participants, we will choose studies with more complete data and a larger sample size. Only articles published in English were included.

\section{2 eligibility criteria}

The meta-analysis included cross-sectional studies and case-control studies. The subjects included in the meta-analysis were people under 18 years old, which compared the cardiovascular risk factors of patients with $\mathrm{SCH}$ (case group) and people with normal thyroid function (control group) including at least one cardiovascular risk factor, including any of the four lipid profile parameters, intima-media thickness (IMT), insulin resistance, and isovolumic relaxation time (IVRT). 


\subsection{Quality assessment and data extraction}

Our study mainly includes case-control studies and cross-sectional studies. The Newcastle-Ottawa Scale (NOS) ${ }^{22}$ used to be used to evaluate biases in studies included in this meta-analysis. This scale is evaluated from three aspects, including object selection, comparability, outcome, and exposure. By comparing this scale, all studies were be divided into three quality grades based on scores: high, medium, and low, and high-quality articles score 7-9 stars, medium quality is 4-6 stars, and the lowest is 0-3 stars. See Table 2 for details.

The data were extracted by two investigators (HD, PPH) and reviewed by a third (XLQ). The following information was be extracted: author, study design, year of publication, TSH cutoff value to define SCH, FT4 measurement, characteristics of study populations (sample size, area, and mean age), mean value, and standard deviation of results in both SH and EU groups.

\subsection{Data synthesis}

We standardized the units of all the results: the units of cholesterol (TC, LDL-C, and HDL-C) and triglyceride (TG) were multiplied by 38.67 and 88.57 respectively to convert from $\mathrm{mmol} / \mathrm{L}$ to $\mathrm{mg} / \mathrm{dL}$. We assessed heterogeneity using the $\mathrm{I}^{2}$ statistics. When the $\mathrm{I}^{2}$ value is 0 , there is no heterogeneity; low heterogeneity occurs when $\mathrm{I}^{2}$ is less than $25 \%$, high heterogeneity occurs when $\mathrm{I}^{2}$ is greater than $50 \%$, and moderate heterogeneity occurs between the two. If the $\mathrm{I}^{2}$ statistic exceeded $50 \%$, the random effect model will be utilized to summarize the study, and if it is not more than $50 \%$, the fixed effects model will be applied. Weighted mean difference (WMD) and 95\% confidence interval (Cl) for continuous variables served to represent the differences between the case group and the control group. When moderate or higher heterogeneity is present, subgroup analysis was adopted to explain the causes of heterogeneity. We conducted a subgroup analysis of study type, study country, NOS score, TSH cutoff, obesity, and SCH degree. The sensitivity analysis assessed the stability of the results against the overall effect by "leave-one-out". When the system review contains more than 10 articles, funnel plots and egger regression test was be made to evaluate publication bias. In this study, the statistically significant value was $p<0.05$ for two tails. RevMan, version5.3 Windows (Cochrane Collaboration, Oxford, UK).was be used to analyze the statistical data.

\section{Results}

3.1 Study selection: After eliminating repeated citations, 270 articles were found. First, 209 articles unrelated to SCH and cardiovascular risk factors were excluded from the reading summary, then, the next step is by reading the full text to filter: 14 studies were excluded because there were no relevant outcomes, 14 studies were excluded because there was no control between the euthyroid group and the SCH patients group, 1 study did not meet the requirements of observational study and 19 studies were excluded because they did not meet inclusion criteria or lacked data. As for the uniform data articles, we only take the research with more complete data and a larger sample size, so there are 2 articles excluded. Finally, 11 studies were included in our analysis (Figure 1). A total of 3995 participants were included, of whom 817 children and adolescents had SCH, and 3,178 were euthyroid.

9 studies $^{23-31}$ compared TC levels in 753 SCH patients and 3097 controls. 8 studies ${ }^{23-29,32}$ (540 cases and 1923 controls) evaluated TG, 6 studies ${ }^{23-27,29}$ reported LDL ( 453 cases and 1832 controls), $8^{23-27,29,31,32}$ reported HDL ( 715 cases and 3107 controls), $5^{24-27,29}$ reported insulin resistance (312 cases and 1160 controls), and 3 studies ${ }^{24,28,29}$ (112cases and 83 controls) assessed CIMT, isovolumic relaxation time (IVRT) was evaluated in 3 studies ${ }^{29,32,33}$ (91 cases and 110 controls).

3.2 Study characteristics: The main characteristics of the studies are shown in Table1. 7 studies are case-control studies, and the remaining four were crosssectional studies. 4 studies included only people with mild SCH as case groups. According to the NOS, 6 studies are of high quality.

3.3 Lipid profile: Serum cholesterol was assessed in 9 studies involving a total of 3850 participants. Meta-analysis results showed that the TC level of SCH patients was significantly increased compared with the control group (Figure $2 \mathrm{~A}$, WMD $=6.39,95 \% \mathrm{Cl}$ : 4.02-8.76, $\mathrm{P}<0.00001$ ). There was low heterogeneity between studies $\left(I^{2}=10 \% ; P=0.35\right)$. Because the number of articles is less than 10 , the publication bias is not considered. Subgroup analysis was not performed because of the low heterogeneity of the literature. The results were robust by comparing and analyzing the sensitivity of the articles.

Serum triglycerides were evaluated in 8 studies involving 2465 participants. It turns out that the TG level of patients with SCH was significantly higher than that of the control group (Figure $2 \mathrm{~B}, \mathrm{WMD}=9.92,95 \% \mathrm{Cl}$ : 5.59-14.24, $\mathrm{P}<0.00001)$ without heterogeneity among studies $\left(\mathrm{I}^{2}=0 \%\right.$; $\left.\mathrm{P}=0.86\right)$. Through sensitivity analysis, the results are robust.

Seven studies, evaluating a total of 2285 participants, showed a significant increase in serum LDL in SCH patients than in control subjects (Figure 2C, $\mathrm{WMD}=4.10,95 \% \mathrm{Cl}: 1.45-6.75, \mathrm{P}=0.002)$, and the heterogeneity between studies was moderate $\left(\mathrm{I}^{2}=44 \%\right.$; $\left.\mathrm{P}=0.11\right)$. Through sensitivity analysis, the results are robust. To keep the results free from confounding factors, subgroup analysis was performed. By subgroup analysis of the diagnostic thresholds for $\mathrm{SCH}$, we found that when the cut-off value of TSH used in the study was less than $5 \mathrm{mIU} / \mathrm{L}(\mathrm{n}=4)$, a larger WMD value was reported $(\mathrm{WMD}=4.52,95 \% \mathrm{Cl}$ : 1.59 -

$7.45, P=0.003)$ and there was no heterogeneity between studies $\left(I^{2}=0 \% ; P=0.51\right)$.

Serum HDL was assessed in 8 studies, involving a total of 3822 individuals, indicated that there was no significant difference between the SCH group and the control group (Figure 2D, WMD =-1.81, 95\% Cl: $-4.44-0.81, \mathrm{P}=0.18)$ with significant heterogeneity among studies $\left(\mathrm{I}^{2}=85 \%\right.$; $\left.\mathrm{P}<0.00001\right)$. Subgroup analysis of study type, study country, NOS, TSH cutoff, obesity, and SCH degree did not reveal the source of heterogeneity. Through sensitivity analysis, the results are robust. 
3.4 Intima-media thickness: The data of IMT came from 3 studies, involving 195 participants. The difference between the two groups was not statistically significant (Figure 2E, WMD $=0.02,95 \% \mathrm{Cl}:-0.01-0.06, \mathrm{P}=0.23$ ) with high heterogeneity among studies $\left(\mathrm{I}^{2}=77 \%\right.$; $\left.\mathrm{P}=0.01\right)$. After excluding Isik $2016^{28}$ through sensitivity analysis, the results of meta-analysis showed that there was no heterogeneity in the remaining articles $\left(\mathrm{WMD}=0.00,95 \% \mathrm{Cl}:-0.03-0.03, \mathrm{P}=0.85, \mathrm{I}^{2}\right.$ $=0 \% ; P=0.79$.

3.5 Insulin resistance: IR was calculated using the homeostasis model assessment (HOMA-IR) equation formula ${ }^{34}$. 5 studies supplied this data, including 1,472 participants. The results revealed that the differences between the $\mathrm{SCH}$ group and the control group were not statistically significant (Figure $2 \mathrm{~F}$, $W M D=0.34,95 \% \mathrm{Cl}:-0.07-0.75, P=0.11)$ and were accompanied by high heterogeneity $\left(I^{2}=75 \% ; P=0.003\right)$. Subgroup analysis of article types revealed that case-control trials reported higher $\mathrm{WMD}$ value $(\mathrm{WMD}=0.46,95 \% \mathrm{Cl}: 0.06-0.87, \mathrm{P}=0.02)$ and less heterogeneity $\left(\mathrm{I}^{2}=48 \% ; \mathrm{P}=0.17\right)$. Sensitivity analysis showed that the results were unstable.

3.6 Isovolumic relaxation time: 3 studies with a total of 201 participants indicated higher IVRT values in the SCH group compared to the control group (Figure 2G, WMD=7.85, 95\% Cl: 3.99-11.72, P<0.0001) with significant heterogeneity among studies $\left(\mathrm{I}^{2}=58 \% ; \mathrm{P}=0.09\right)$. After excluding Yadav 2017 29 through sensitivity analysis, the results of meta-analysis showed that there was no heterogeneity in the remaining articles(WMD=9.32, 95\% $\mathrm{Cl}$ : $6.86-11.79$, $\left.\mathrm{P}<0.00001, \mathrm{I}^{2}=0 \% ; \mathrm{P}=0.50\right)$.

\section{Discussion}

In this meta-analysis, we included 11 articles that provided data on 817 cases of subclinical hypothyroidism and 3178 cases of children with normal thyroid function. All the included articles were in English, including 6 articles of high quality and 5 articles of medium quality. By analyzing these data, it was found that children and adolescents with SCH had higher TC, TG, and LDL than normal subjects, while the HDL was no significant difference between the SCH group and the control group. In the analysis, it was also concluded that there was no significant difference in insulin resistance and intima-media thickness between $\mathrm{SCH}$ patients and normal children, but the isovolumic relaxation time of SCH patients was significantly increased compared with that of normal children. However, due to the small number of literature and unstable results, it requires further discussion.

In the case of lipids, several studies have demonstrated that changes in the lipid profile are associated with cardiovascular risk ${ }^{35}$. As high levels of TC, LDL, and TG, as well as low levels of $\mathrm{HDL}$, are risk factors for cardiovascular disease ${ }^{36}$. Since the thyroid hormone regulates many enzymes in the transport of lipoproteins, the lipid profile of $\mathrm{SCH}$ patients is more likely to chang $\mathrm{e}^{37}$. The thyroid hormone also increases hepatic cholesterol synthesis by inducing. hydroxymethylglutaryl coenzyme A (HMG CoA) reductase and decreases intestinal cholesterol absorption ${ }^{38-40}$. Thyroid hormone can also affect the expression of LDL receptor ${ }^{40,41}$. Besides, it has been reported that TSH can increase TC level independently ${ }^{42}$. At the same time, the thyroid hormone can increase the activity of lipoprotein lipase and reduce the level of triglyceride ${ }^{43}$. Due to the interaction of multiple mechanisms, the overall effect of SCH on blood lipids is still controversial. Our study showed that SCH patients had higher TC, TG, and LDL than normal subjects. No publication bias was found by funnel plot. This result was per the majority of conclusions of previous studies. A meta-analysis of lipid changes in adult patients with SCH has come to the same conclusion ${ }^{20}$. For HDL, our study did not find significant differences between the two groups, and this result has high and unexplained heterogeneity, which requires careful interpretation and more studies in the future.

The pathological basis of cardiovascular disease is the diffuse thickening and hardening of the large and medium arteries. Endothelial dysfunction in SCH patients may be caused by the decrease of nitric oxide utilization ${ }^{16}$, or indirectly by hypercholesterolemia and hypertension in $\mathrm{SCH}_{\text {patients }}{ }^{44}$. Various clinical studies have demonstrated that IMT is an independent predictor of cardiovascular disease ${ }^{45}$. In a previous meta-analysis of cardiovascular risk in adult SCH patients, they found significant differences in IMT between the case group and the control group, albeit with considerable heterogeneity ${ }^{46}$. However, no significant difference was seen in our study. The reasons may be as follows: First, our study found little literature on this indicator, and the results were heterogeneous and unstable. In the sensitivity analysis, we found that the Isik-Balci's ${ }^{28}$ article was the primary source of heterogeneity. Reviewing this article again, we noted that this may be due to the higher age of the SCH patient group compared to the control group, although there was no statistically significant difference. Secondly, IMT is also bound up with obesity, smoking, age, and other factors, and the huge difference between adults and children in these aspects may also be the reason for the difference in results. More evidence is needed to make sure of intimal injury in SCH children in the future.

Insulin resistance has been suggested as an independent risk factor of atherosclerosis ${ }^{47}$. Since thyroid hormones can be involved in the regulation of blood sugar and blood lipids, patients with thyroid dysfunction are more likely to suffer from a series of metabolic disorders. A retrospective pediatric study found that within the reference range, TSH levels increase with increased insulin and HOMA levels ${ }^{48}$. However, in our study, no significant difference was found between the HOMA value of patients with $\mathrm{SCH}$ and that of the control group, which may be due to the feeble control of potential confounders in the included study.

It has long been reported that subclinical hypothyroidism may lead to diastolic dysfunction. Previous studies have shown that SCH affects the left ventricular function of patients, showing increased isovolumic relaxation time and decreased mean aortic acceleration (a reliable indicator of left ventricular systolic function), and returning to normal after levothyroxine treatment ${ }^{49}$. This may lead to poor physical exercise ability ${ }^{50}$. Its mechanism is not clear, now there are mainly the following kinds: On the one hand, $\mathrm{SCH}$ leads to endothelial dysfunction and arterial stiffness by affecting the production of NO and other pathways ${ }^{51}$. On the other hand, the pathogenesis of diastolic dysfunction might be influenced by TSH stimuli for apoptotic-derived microparticles ${ }^{52}$. Also, other studies have shown that it may also be related to systemic inflammation ${ }^{53}$. Due to the lack of data on children, our analysis included only three 
articles. Even though significant differences were found between the two groups, the results were not robust. The article ${ }^{29}$ that caused the heterogeneity may be due to the high cut-off value of TSH.

There are many limitations to our study. First, some of the observational studies included in our analysis did not control potential confounding factors, so more experimental data are needed to explain this result; secondly, as the cut-off value of TSH for diagnostic SCH has not been determined at present, the cut-off value of included literature is also different, which may lead to some heterogeneity, it needs to be determined by more studies in the future; third, we cannot determine the duration of hypothyroidism, because it has been reported that $\mathrm{SCH}$ in children is a self-limiting disease. In a large pediatric cohort comprising 121052 cases, children with a slightly higher TSH may return to normal within 5 years ${ }^{54}$. Besides, the time and degree of hypothyroidism can significantly affect blood lipid levels. Finally, we cannot give a reasonable explanation for the heterogeneity of HDL in our study, which may be related to other potential confounding factors in the included studies, more clinical studies are needed for further discussion.

\section{Conclusion}

Our analysis indicates that children and adolescents with subclinical hypothyroidism have higher serum TC, TG, LDL levels, which may increase cardiovascular risk. At the same time, IVRT of children and adolescents with $\mathrm{SCH}$ is longer than that of normal people, which also shows that SCH can damage their cardiac function. Therefore, the cardiovascular function of children with SCH should be closely monitored. For HDL, insulin resistance, and IMT, The difference between the two groups was not statistically significant, and further research is necessary. Since our study only involves observational experiments, the results need to be more cautious. In the future, large-scale, long-term clinical studies will be needed to further confirm the risk of cardiovascular events in children with $\mathrm{SCH}$, whether treatment is needed, and whether treatment will reduce the risk.

\section{Abbreviations}

$\mathrm{SCH}=$ subclinical hypothyroidism, $\mathrm{TSH}=$ thyrotropin, $\mathrm{FT} 4=$ free thyroxine, $\mathrm{TC}=$ total cholesterol, $\mathrm{HDL}-\mathrm{C}=$ high-density lipoprotein cholesterol, $\mathrm{TG}=$ triglycerides, LDL-C= low-density lipoprotein cholesterol, IMT= intima-media thickness, CNKI= China National Knowledge Infrastructure, VIP= China Science and Technology Journal Database, NOS= the Newcastle-Ottawa Scale, EU= euthyroid, PRISMA =Preferred Reporting Items for Systematic Reviews and MetaAnalyses, MOOSE =Meta-analysis of Observational Studies in Epidemiology, MeSH =medical subheadings, WMD=weighted mean difference, IVRT=Isovolumic relaxation time, IR=insulin resistance, $\mathrm{HMG}$ CoA= hydroxymethylglutaryl coenzyme A.

\section{Declarations}

\section{Acknowledgments}

Not applicable

\section{Funding}

This work was supported by the Subsidy Funds for Improving Medical Services and Guarantee Capabilities (Major Incurable Diseases) [grant numbers: CYW2019079]

\section{Contributions}

Idea conception: HD, XW. Literature retrieval: HD, QW, XLQ. Methodology: HD, XW. Writing-initial manuscript: HD, PPH. Review guarantor: QC. All authors participated in the revision of the manuscript and agreed to publish it.

\section{Ethical approval}

Not required- there is only for the data in the published literature, and does not collect personal primary data.

\section{Consent for publication}

Not required.

\section{Competing interests}

None declared.

\section{Availability of data and materials}

All data generated or analyzed during this meta-analysis can be found in the references.

\section{References}

1. Crisafulli G, Aversa T, Zirilli G, et al. Subclinical Hypothyroidism in Children: When a Replacement Hormonal Treatment Might Be Advisable. Front Endocrinol (Lausanne). 2019;10:109.

2. Gallizzi R, Crisafulli C, Aversa T, et al. Subclinical hypothyroidism in children: is it always subclinical? Ital J Pediatr. 2018;44(1):25. 
3. Leung AKC, Leung AAC. Evaluation and management of the child with hypothyroidism. World J Pediatr. 2019;15(2):124-134.

4. Barr ML, Chiu HK, Li N, et al. Thyroid Dysfunction in Children Exposed to lodinated Contrast Media. J Clin Endocrinol Metab. 2016;101(6):2366-2370.

5. Elmlinger MW, Kuhnel W, Lambrecht HG, Ranke MB. Reference intervals from birth to adulthood for serum thyroxine (T4), triiodothyronine (T3), free T3, free T4, thyroxine binding globulin (TBG) and thyrotropin (TSH). Clin Chem Lab Med. 2001;39(10):973-979.

6. Hollowell JG, Staehling NW, Flanders WD, et al. Serum TSH, T(4), and thyroid antibodies in the United States population (1988 to 1994$)$ : National Health and Nutrition Examination Survey (NHANES III). J Clin Endocrinol Metab. 2002;87(2):489-499.

7. Brabant G, Beck-Peccoz P, Jarzab B, et al. Is there a need to redefine the upper normal limit of TSH? Eur J Endocrinol. 2006;154(5):633-637.

8. Biondi B, Cappola AR, Cooper DS. Subclinical Hypothyroidism: A Review. JAMA. 2019;322(2):153-160.

9. Mazzaferri EL. Subclinical thyroid disorders and cognitive performance among adolescents in the United States. Yearbook of Endocrinology. 2007;2007:183-185.

10. Peeters RP. Subclinical Hypothyroidism. N Engl J Med. 2017;376(26):2556-2565.

11. Ichiki T. Thyroid hormone and atherosclerosis. Vascul Pharmacol. 2010;52(3-4):151-156.

12. Sundaram V, Hanna AN, Koneru L, Newman HA, Falko JM. Both hypothyroidism and hyperthyroidism enhance low density lipoprotein oxidation. $J$ Clin Endocrinol Metab. 1997;82(10):3421-3424.

13. Danese MD, Ladenson PW, Meinert CL, Powe NR. Clinical review 115: effect of thyroxine therapy on serum lipoproteins in patients with mild thyroid failure: a quantitative review of the literature. J Clin Endocrinol Metab. 2000;85(9):2993-3001.

14. Staub JJ, Althaus BU, Engler $\mathrm{H}$, et al. Spectrum of subclinical and overt hypothyroidism: effect on thyrotropin, prolactin, and thyroid reserve, and metabolic impact on peripheral target tissues. The American journal of medicine. 1992;92(6):631-642.

15. Graettinger JS, Muenster JJ, Checchia CS, Grissom RL, Campbell JA. A correlation of clinical and hemodynamic studies in patients with hypothyroidism. The Journal of clinical investigation. 1958;37(4):502-510.

16. Taddei S, Caraccio N, Virdis A, et al. Impaired endothelium-dependent vasodilatation in subclinical hypothyroidism: beneficial effect of levothyroxine therapy. J Clin Endocrinol Metab. 2003;88(8):3731-3737.

17. Mizuma H, Murakami M, Mori M. Thyroid hormone activation in human vascular smooth muscle cells: expression of type II iodothyronine deiodinase. Circulation research. 2001;88(3):313-318.

18. Chen X, Zhang N, Cai Y, Shi J. Evaluation of left ventricular diastolic function using tissue Doppler echocardiography and conventional doppler echocardiography in patients with subclinical hypothyroidism aged $<60$ years: a meta-analysis. J Cardiol. 2013;61(1):8-15.

19. Gao N, Zhang W, Zhang YZ, Yang Q, Chen SH. Carotid intima-media thickness in patients with subclinical hypothyroidism: a meta-analysis. Atherosclerosis. 2013;227(1):18-25.

20. Liu XL, He S, Zhang SF, et al. Alteration of lipid profile in subclinical hypothyroidism: a meta-analysis. Med Sci Monit. 2014;20:1432-1441.

21. Stroup DF, Berlin JA, Morton SC, et al. Meta-analysis of observational studies in epidemiology: a proposal for reporting. Meta-analysis Of Observational Studies in Epidemiology (MOOSE) group. Jama. 2000;283(15):2008-2012.

22. Stang A. Critical evaluation of the Newcastle-Ottawa scale for the assessment of the quality of nonrandomized studies in meta-analyses. Eur $J$ Epidemiol. 2010;25(9):603-605.

23. Unal E, Akın A, Yıldırım R, Demir V, Yildiz I, Haspolat YK. Association of Subclinical Hypothyroidism with Dyslipidemia and Increased Carotid IntimaMedia Thickness in Children. Journal of clinical research in pediatric endocrinology. 2017;9(2):144-149.

24. Farghaly HS, Metwalley KA, Raafat DM, Algowhary M, Said GM. Epicardial Fat Thickness in Children with Subclinical Hypothyroidism and Its Relationship to Subclinical Atherosclerosis: A Pilot Study. Horm Res Paediatr. 2019;92(2):99-105.

25. Kara O. Influence of subclinical hypothyroidism on metabolic parameters in obese children and adolescents. Clinical and experimental pediatrics. 2020;63(3):110-114.

26. Radetti G, Grugni G, Lupi F, et al. The relationship between hyperthyrotropinemia and metabolic and cardiovascular risk factors in a large group of overweight and obese children and adolescents. Journal of endocrinological investigation. 2017;40(12):1311-1319.

27. Jin HY. Prevalence of subclinical hypothyroidism in obese children or adolescents and association between thyroid hormone and the components of metabolic syndrome. Journal of paediatrics and child health. 2018;54(9):975-980.

28. Isik-Balci Y, Agladioglu S, Agladioglu K, et al. Impaired Hemorheological Parameters and Increased Carotid Intima-Media Thickness in Children with Subclinical Hypothyroidism. Horm Res Paediatr. 2016;85(4):250-256.

29. Yadav Y, Saikia UK, Sarma D, Hazarika M. Cardiovascular Risk Factors in Children and Adolescents with Subclinical Hypothyroidism. Indian journal of endocrinology and metabolism. 2017;21(6):823-829.

30. Atabek ME, Pirgon O, Erkul I. Plasma homocysteine concentrations in adolescents with subclinical hypothyroidism. Journal of pediatric endocrinology \& metabolism: JPEM. 2003;16(9):1245-1248.

31. Dahl AR, Iqbal AM, Lteif AN, Pittock ST, Tebben PJ, Kumar S. Mild subclinical hypothyroidism is associated with paediatric dyslipidaemia. Clin Endocrinol (Oxf). 2018;89(3):330-335.

32. Brienza C, Grandone A, Di Salvo G, et al. Subclinical hypothyroidism and myocardial function in obese children. Nutr Metab Cardiovasc Dis. 2013;23(9):898-902. 
33. Irdem A, Aydin Sahin D, Kervancioglu M, et al. Evaluation of P-Wave Dispersion, Diastolic Function, and Atrial Electromechanical Conduction in Pediatric Patients with Subclinical Hypothyroidism. Echocardiography (Mount Kisco, NY). 2016;33(9):1397-1401.

34. Wallace TM, Levy JC, Matthews DR. Use and abuse of HOMA modeling. Diabetes care. 2004;27(6):1487-1495.

35. Després JP, Golay A, Sjöström L. Effects of rimonabant on metabolic risk factors in overweight patients with dyslipidemia. N Engl J Med. 2005;353(20):2121-2134.

36. Langsted A, Nordestgaard BG. Nonfasting versus fasting lipid profile for cardiovascular risk prediction. Pathology. 2019;51(2):131-141.

37. Duntas LH. Thyroid disease and lipids. Thyroid. 2002;12(4):287-293.

38. Tan KC, Shiu SW, Kung AW. Plasma cholesteryl ester transfer protein activity in hyper- and hypothyroidism. J Clin Endocrinol Metab. 1998;83(1):140143.

39. Gälman C, Bonde Y, Matasconi M, Angelin B, Rudling M. Dramatically increased intestinal absorption of cholesterol following hypophysectomy is normalized by thyroid hormone. Gastroenterology. 2008;134(4):1127-1136.

40. Pearce EN. Update in lipid alterations in subclinical hypothyroidism. J Clin Endocrinol Metab. 2012;97(2):326-333.

41. Shin DJ, Osborne TF. Thyroid hormone regulation and cholesterol metabolism are connected through Sterol Regulatory Element-Binding Protein-2 (SREBP-2). The Journal of biological chemistry. 2003;278(36):34114-34118.

42. Xu C, Yang X, Liu W, et al. Thyroid stimulating hormone, independent of thyroid hormone, can elevate the serum total cholesterol level in patients with coronary heart disease: a cross-sectional design. Nutrition \& metabolism. 2012;9(1):44.

43. Lam KS, Chan MK, Yeung RT. High-density lipoprotein cholesterol, hepatic lipase and lipoprotein lipase activities in thyroid dysfunction-effects of treatment. The Quarterly journal of medicine. 1986;59(229):513-521.

44. Giannotti G, Landmesser U. Endothelial dysfunction as an early sign of atherosclerosis. Herz. 2007;32(7):568-572.

45. Simon A, Megnien JL, Chironi G. The value of carotid intima-media thickness for predicting cardiovascular risk. Arterioscler Thromb Vasc Biol. 2010;30(2):182-185.

46. Yao K, Zhao T, Zeng L, et al. Non-invasive markers of cardiovascular risk in patients with subclinical hypothyroidism: A systematic review and metaanalysis of 27 case control studies. Sci Rep. 2018;8(1):4579.

47. Di Pino A, DeFronzo RA. Insulin Resistance and Atherosclerosis: Implications for Insulin-Sensitizing Agents. Endocr Rev. 2019;40(6):1447-1467.

48. Nader NS, Bahn RS, Johnson MD, Weaver AL, Singh R, Kumar S. Relationships between thyroid function and lipid status or insulin resistance in a pediatric population. Thyroid. 2010;20(12):1333-1339.

49. Biondi B, Fazio S, Palmieri EA, et al. Left ventricular diastolic dysfunction in patients with subclinical hypothyroidism. $J$ Clin Endocrinol Metab. 1999;84(6):2064-2067.

50. Biondi B, Palmieri EA, Lombardi G, Fazio S. Effects of subclinical thyroid dysfunction on the heart. Ann Intern Med. 2002;137(11):904-914.

51. Lee S-W, Cho K-I, Kim H-S, Heo J-H, Cha T-J. The Impact of Subclinical Hypothyroidism or Thyroid Autoimmunity on Coronary Vasospasm in Patients without Associated Cardiovascular Risk Factors. Korean Circ J. 2015;45(2):125-130.

52. Berezin AE, Kremzer AA, Martovitskaya YV, Samura TA, Berezina TA. Pattern of circulating endothelial-derived microparticles among chronic heart failure patients with dysmetabolic comorbidities: The impact of subclinical hypothyroidism. Diabetes \& metabolic syndrome. 2016;10(1):29-36.

53. Gupta G, Sharma P, Kumar P, Itagappa M. Study on Subclinical Hypothyroidism and its Association with Various Inflammatory Markers. Journal of clinical and diagnostic research: JCDR. 2015;9(11):Bc04-06.

54. Lazar L, Frumkin RB, Battat E, Lebenthal Y, Phillip M, Meyerovitch J. Natural history of thyroid function tests over 5 years in a large pediatric cohort. $J$ Clin Endocrinol Metab. 2009;94(5):1678-1682.

\section{Tables}

Table1. Characteristics of included studies. 


\begin{tabular}{|c|c|c|c|c|c|c|c|c|c|}
\hline Author & Year & Country & $\begin{array}{l}\text { Study } \\
\text { design }\end{array}$ & $\begin{array}{l}\text { Participants } \\
\text { (SCH/EU) }\end{array}$ & $\begin{array}{l}\text { Age } \\
\text { (SCH/EU) }\end{array}$ & $\begin{array}{l}\text { TSH } \\
\text { cutoff } \\
\text { value }\end{array}$ & $\begin{array}{l}\text { T4 } \\
\text { measured? }\end{array}$ & Measure outcomes & $\begin{array}{l}\text { NOS } \\
\text { score }\end{array}$ \\
\hline Dahl2018 & 2018 & USA & $\begin{array}{l}\text { Cross- } \\
\text { sectional } \\
\text { study }\end{array}$ & $228 / 1215$ & $13.3 \pm 4.2 / 13.4 \pm 3.9$ & $>5 \mathrm{mIU} / \mathrm{L}$ & $\mathrm{Y}$ & $\mathrm{TC}, \mathrm{c}-\mathrm{HDL}$ & 7 \\
\hline Isik 2016 & 2016 & Turkey & $\begin{array}{l}\text { Case- } \\
\text { control } \\
\text { study }\end{array}$ & $53 / 31$ & $9.25 \pm 4.2 / 7.19 \pm 5.15$ & $>5 \mathrm{mIU} / \mathrm{L}$ & $\mathrm{Y}$ & $\begin{array}{l}\text { triglyceride, TC, } \\
\text { CIMT }\end{array}$ & 8 \\
\hline Jin 2018 & 2018 & $\begin{array}{l}\text { South } \\
\text { Korea }\end{array}$ & $\begin{array}{l}\text { Cross- } \\
\text { sectional } \\
\text { study }\end{array}$ & $154 / 950$ & $14.4 \pm 3 / 14.7 \pm 2.8$ & $\underset{4.5 \mathrm{mIU} / \mathrm{L}}{\geq}$ & $\mathrm{Y}$ & $\begin{array}{l}\text { triglyceride, c-LDL, } \\
\text { TC, c-HDL, HOMA-IR }\end{array}$ & 8 \\
\hline Kara 2020 & 2020 & Turkey & $\begin{array}{l}\text { Cross- } \\
\text { sectional } \\
\text { study }\end{array}$ & $77 / 138$ & $12.32 \pm 2.81 / 12.33 \pm 2.83$ & $>5 \mathrm{mlU} / \mathrm{L}$ & $\mathrm{Y}$ & $\begin{array}{l}\text { triglyceride, c-LDL, } \\
\text { TC, c-HDL, HOMA-IR }\end{array}$ & 7 \\
\hline Radetti 2017 & 2017 & Italy & $\begin{array}{l}\text { Cross- } \\
\text { sectional } \\
\text { study }\end{array}$ & $125 / 645$ & $13.8 \pm 2.7 / 14.5 \pm 2.5$ & $>4.5 \mathrm{mlU} / \mathrm{L}$ & $\mathrm{Y}$ & $\begin{array}{l}\text { triglyceride, c-LDL, } \\
\text { TC, C-HDL, HOMA-IR, } \\
\text { hsCRP }\end{array}$ & 6 \\
\hline Unal 2017 & 2017 & Turkey & $\begin{array}{l}\text { Case- } \\
\text { control } \\
\text { study }\end{array}$ & $38 / 38$ & $8.1 \pm 3.6 / 8.9 \pm 2.4$ & $>4.2 \mathrm{mlU} / \mathrm{L}$ & $\mathrm{Y}$ & $\begin{array}{l}\text { triglyceride, c-LDL, } \\
\text { TC, c-HDL, CIMT }\end{array}$ & 6 \\
\hline Yadav 2017 & 2017 & India & $\begin{array}{l}\text { Case- } \\
\text { control } \\
\text { study }\end{array}$ & $27 / 20$ & $10.98 \pm 2.36 / 10.85 \pm 2.44$ & $>7.5 \mathrm{mlU} / \mathrm{L}$ & $\mathrm{Y}$ & $\begin{array}{l}\text { triglyceride, c-LDL, } \\
\text { TC, C-HDL, HOMA-IR, } \\
\text { hsCRP, CIMT, IVRT }\end{array}$ & 7 \\
\hline Farghaly2019 & 2019 & Egypt & $\begin{array}{l}\text { Case- } \\
\text { control } \\
\text { study }\end{array}$ & $32 / 32$ & $13.6 \pm 2.5 / 13.2 \pm 2.1$ & $>4 \mathrm{mIU} / \mathrm{L}$ & $\mathrm{Y}$ & $\begin{array}{l}\text { triglyceride, c-LDL, } \\
\text { TC, C-HDL, HOMA-IR, } \\
\text { hsCRP, CIMT }\end{array}$ & 7 \\
\hline Atabek 2003 & 2003 & Turkey & $\begin{array}{l}\text { Case- } \\
\text { control } \\
\text { study }\end{array}$ & $19 / 19$ & $15 \pm 1.8 / 14.9 \pm 1.9$ & $>4 \mathrm{mIU} / \mathrm{L}$ & Y & $\mathrm{TC}$ & 6 \\
\hline Brienza 2013 & 2013 & Italy & $\begin{array}{l}\text { Case- } \\
\text { control } \\
\text { study }\end{array}$ & $34 / 60$ & $9.7 \pm 2.7 / 10.4 \pm 2.6$ & $>4.2 \mathrm{mlU} / \mathrm{L}$ & $\mathrm{Y}$ & $\begin{array}{l}\text { triglyceride, c-HDL, } \\
\text { IVRT }\end{array}$ & 6 \\
\hline Irdem 2016 & 2016 & Turkey & $\begin{array}{l}\text { Case- } \\
\text { control } \\
\text { study }\end{array}$ & $30 / 30$ & $7.8 \pm 3.2 / 8.4 \pm 3.6$ & $>4.2 \mathrm{mlU} / \mathrm{L}$ & $\mathrm{Y}$ & IVRT & 6 \\
\hline
\end{tabular}

Table 2: Newcastle-Ottawa Scale

\begin{tabular}{|c|c|c|c|c|c|c|c|c|c|}
\hline Study ID & $\begin{array}{l}\text { 01. Is the } \\
\text { case } \\
\text { definition } \\
\text { adequate? } \\
\text { (0-1 star) }\end{array}$ & $\begin{array}{l}02 \text {. } \\
\text { Representativeness } \\
\text { of the cases } \\
\text { (0-1 star) }\end{array}$ & $\begin{array}{l}03 . \\
\text { Selection } \\
\text { of } \\
\text { Controls } \\
\text { (0-1 star) }\end{array}$ & $\begin{array}{l}04 . \\
\text { Definition } \\
\text { of } \\
\text { Controls } \\
\text { (0-1 star) }\end{array}$ & $\begin{array}{l}05 . \\
\text { Comparability } \\
\text { of cases and } \\
\text { controls on } \\
\text { the basis } \\
\text { (0-2 stars) }\end{array}$ & $\begin{array}{l}06 . \\
\text { Ascertainment } \\
\text { of exposure } \\
\text { (0-1 star) }\end{array}$ & $\begin{array}{l}\text { 07. Same } \\
\text { method of } \\
\text { ascertainment } \\
\text { for cases and } \\
\text { controls } \\
\text { (0-1 star) }\end{array}$ & $\begin{array}{l}\text { 08. Non- } \\
\text { Response } \\
\text { rate } \\
\text { (0-1 star) }\end{array}$ & $\begin{array}{l}\text { Total } \\
(0-9 \\
\text { stars })\end{array}$ \\
\hline Dahl 2018 & प & प & & प & प्र & & प & प & 7 \\
\hline Isik 2016 & प & प & & प & प्रा & 口 & प & प & 8 \\
\hline Jin 2018 & प & प & प & प & 吅 & & प & प & 8 \\
\hline Kara 2020 & प & प & & प & प्र & & प & प & 7 \\
\hline Radetti 2017 & & प & प & प & प & & प & प & 6 \\
\hline Unal 2017 & & प & & प & प & प & प & प & 6 \\
\hline Yadav 2017 & & प & & प & प्र & प & प & प & 7 \\
\hline Farghaly 2019 & प & & & प & 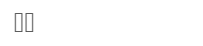 & प & प & प & 7 \\
\hline Atabek 2003 & प & & & प & प & प & प & प & 6 \\
\hline Brienza 2013 & & & & प & 吅 & प & प & प & 6 \\
\hline Irdem 2016 & & & & प & प्र & प & प & प & 6 \\
\hline
\end{tabular}

\section{Figures}




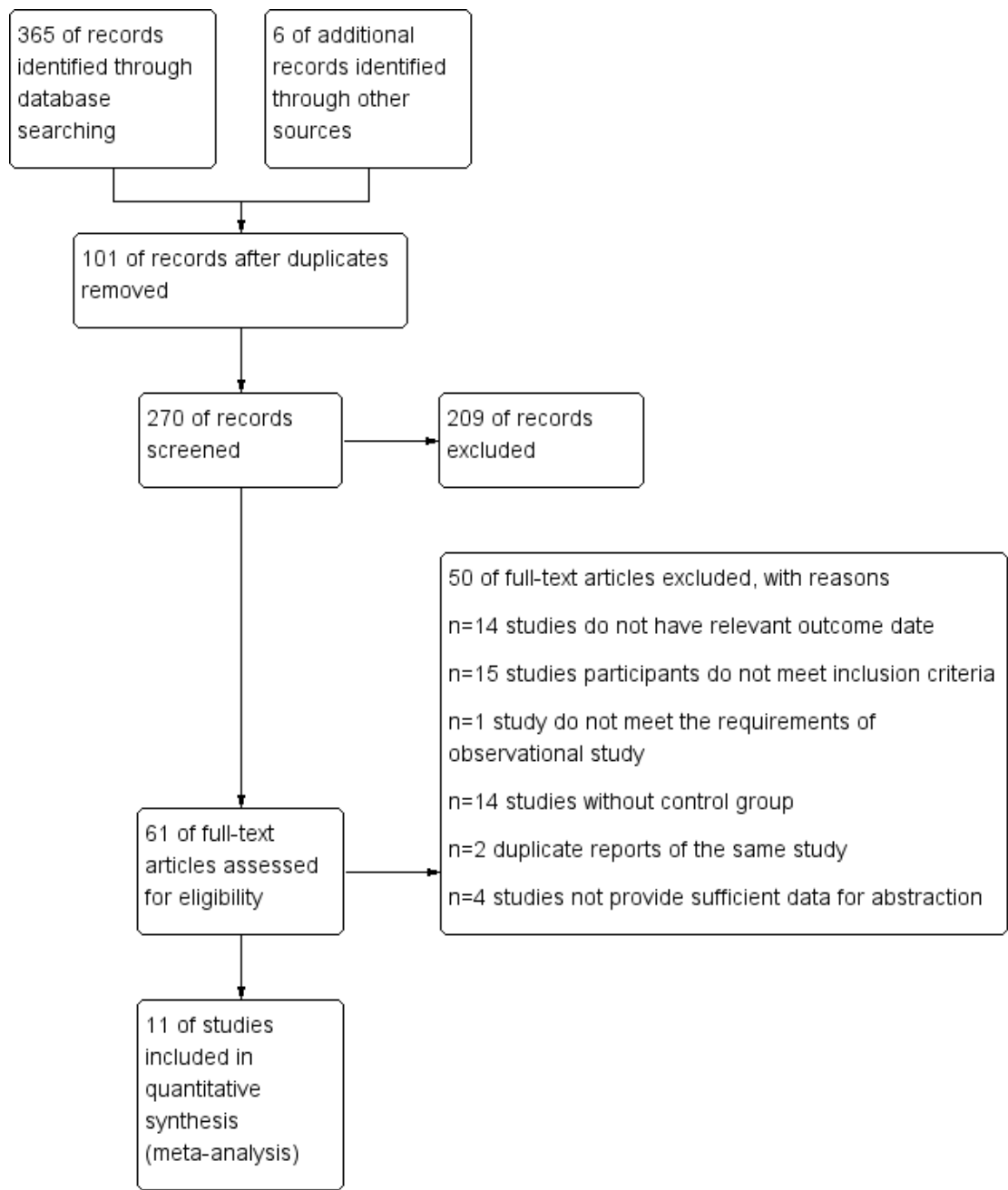

\section{Figure 1}

flow diagram. 


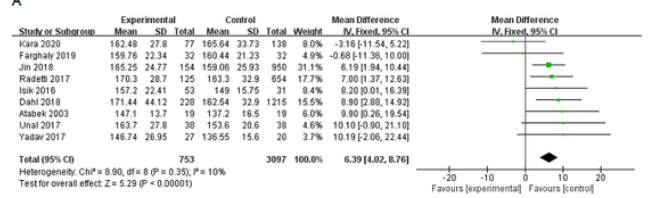

в
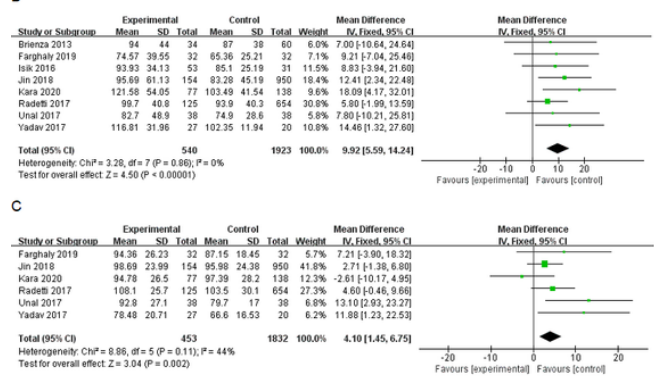

D

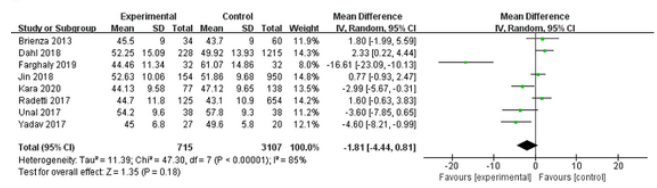

E
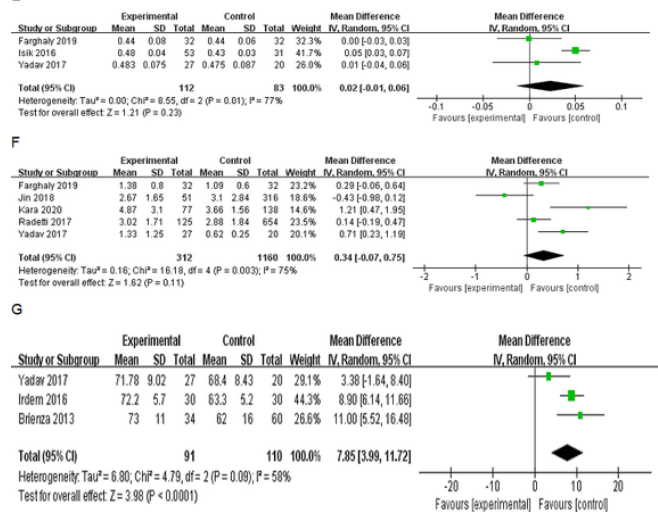

Figure 2

Forest plots for the effect of SCH patients on cardiovascular risk markers including Serum cholesterol(A), triglycerides(B), LDL(C), HDL(D), IMT(E), Insulin resistance(F), Isovolumic relaxation time(G). 